\title{
Isolation and Screening of Phosphate Solubilizing Bacteria from Paddy Rhizosphere Soil
}

\author{
Eramma $^{1}$, Mahadevaswamy ${ }^{1}$, Satyanarayana Rao ${ }^{2}$, Y. M. Ramesh $^{3}$ \\ and Nagaraj M. Naik ${ }^{1}$ \\ ${ }^{1}$ Department of Agricultural Microbiology, AC Raichur, UAS, Raichur, India \\ ${ }^{2} U A S$, Raichur, Karanataka, India \\ ${ }^{3}$ Department of Agronomy, ARS Dadesugur, UAS, Raichur, India
}

*Corresponding author

Keywords

Phosphate,

Bacteria, Paddy,

Pikovsakaya's

medium

Article Info

Accepted:

05January 2020

Available Online:

10 February 2020

A B S T R A C T

Phosphorus is one of essential macro-minerals for the growth and development of plant. The main of this study to isolate the PSB and screened for its solubilization efficiency on Pikovskaya's agar and broth at different incubation period. Totally 40 PSB were isolated from paddy rhizosphere soils of Raichur and Koppal districts. PSB isolates were studied for zone of solubilization, solubilization efficiency, solubilization index, ph change titrable acidity and phosphatase activity. The solubilization zone, efficiency and index were highest on $6^{\text {th }}$ day of incubation period. From that 10 isolates were found to be good phosphate solubilizer. Among 10 isolates, isolate PPSB-21 showed highest zone of solubilization $(18.4 \mathrm{~mm})$ phosphate solubilization efficiency $(253.84 \%)$ and solubilization index (3.53) on Pikovsakaya's medium. These efficient isolates can be used as biofertilizer.

\section{Introduction}

Rice (Oryza sativa L.) is one of the most important cereal crops in the world belongs to the family Poaceae. Rice is the important food grain and staple food for over the billions of people in most of the countries particularly in East Asia. It's a major part of balanced diet and rich source of energy and carbohydrate. It is extensively grown food crop in 114 countries across the world, occupying area of about 163.20 million hacters of farm lands with annual production of over 758.9 million tonnes with a productivity of $4448 \mathrm{~kg} \mathrm{ha}^{-1}$ per hectare.

Phosphorus is one of essential macro-minerals for the growth and development of plant 
(Schachtman et al., 1998). It is a major component in ATP, the molecule that provides energy to the plant for such processes as photosynthesis, protein synthesis, nutrient translocation, nutrient uptake and respiration. In addition, $\mathrm{P}$ has been observed to increase root growth and influence early maturity, straw strength, crop quality and disease resistance (Deepak Kumar, 2011). The available phosphorus in soils of India is generally poor. Efficiency of $\mathrm{P}$ fertilizer is around 10-25\% throughout the world (Isheword, 1998).

India, majority of the phosphorus provided in the form of chemical fertilizer. Inorganic $P$ occurs in soil, mostly in insoluble mineral complexes, these insoluble, precipitated forms cannot be absorbed by plants (Rengel and Marschner, 2005). Large amount of phosphorus applied as fertilizes enter into immobile pool through chelating action with highly reactive $\mathrm{Al}^{3+}$ and $\mathrm{Fe}^{2+}$ in acidic soil (Gyaneshwar et al., 2002). In nature, wide range of microbial biosolubilization mechanisms exist which are necessary to maintain global cycle (Whitelaw, 2000).

Phosphorus solubilizing bacteria a group of beneficial bacteria play a key role in soil Phosphate solubilization (Abd-Alla, 1994) there by increasing the bioavailability of soil $\mathrm{P}$ for plants (Zhu et al., 2011). Phosphate solubilization occurs by production of organic acids and released by microorganisms; this release also decreases soil $\mathrm{pH}$ (Rodriguez et $a l ., 2006)$. Organic acids solubilize insoluble $\mathrm{P}$ either by decreasing the $\mathrm{pH}$ or by the complexing the cation which is bound to the $\mathrm{P}$ (Vassilev et al., 2006). The organic acids such as succinic acid, malic acid, propionic acid and oxalic acid are released by Phosphorus solubilizing bacteria (Panhwar et al., 2012), which chelate the cation bound to phosphate and being converted to soluble forms through their hydroxyl and carboxyl groups. Large number of bacteria including species of Pseudomonas, Azospirillum, Azotobacter, Klebsiella, Enterobacter, Alcaligenes, Arthrobacter, Burkholderia, Bacillus, Rhizobium and Serratia have reported to enhance plant growth by with their different plant growth promoting activities including phosphate solubilization (Kumar et al., 2012).

\section{Materials and Methods}

\section{Collection of soil sample}

A total of forty soil samples from rhizosphere of paddy were collected from different locations of Raichur and Koppal district of Karnataka by adopting standard soil sampling methods described by Jackson (1973). Soil samples were collected in sterilized polythene bags. The Polythene bags were properly tied; labeled and at most care was taken to avoid contamination. Soil samples were stored in refrigerator at $4^{\circ} \mathrm{C}$ for the isolation of phosphate solubilizing bacterial isolates.

\section{Analysis of soil chemical properties}

Air dried samples were analysed for $\mathrm{pH}, \mathrm{EC}$, OC, N, P, K and Zn content estimation by following standard procedures.

\section{Isolaton of PSB from paddy rhizosphere soil}

One gram of soil from each sample was suspended in $9 \mathrm{ml}$ blank sterile distilled water and serially diluted up to $10^{-6}$ homogenization of soil was carried out by keeping it on shaker. The dilutions were plated on Pikovskaya's agar medium Pikovaskaya's medium (Pikovskaya's, 1948) contains (grams/liter); Glucose, 10.0gm; $\mathrm{Ca}_{3}\left(\mathrm{PO}_{4}\right)_{2}$, 5.0 gm; $\left(\mathrm{NH}_{4}\right)_{2} \mathrm{SO}_{4}, 0.5 \mathrm{gm} ; \mathrm{NaCl}, 0.2 \mathrm{gm}$; $\mathrm{MgSO}_{4} .7 \mathrm{H}_{2} \mathrm{O}, 0.1 \mathrm{gm}, \mathrm{pH} 7.3 \pm 2$. These plates were kept at $28 \pm 2{ }^{\circ} \mathrm{C}$ for 7 days in order to isolate the PSB. The bacterial colonies 
exhibiting the clearance zone around the colonies were selected, purified, sub-cultured and stored on the slants of Pikovskaya's agar for further studies.

\section{Screening of PSB}

Each of the isolates was screened for their ability to solubilize Tri phosphate Phosphate (TCP) present in the Pikovaskaya's medium. A loopful of bacterial culture was placed on the centre of the same agar plates and incubated for $28 \pm 2{ }^{\circ} \mathrm{C}$ for 6 days. The solubilization zone, efficiency and index were calculated at different incubation period. The phosphate solubilization efficiency was calculated (Kannapiran and Ramkumar, 2011).

$$
\mathrm{SE} \%=\frac{\mathrm{SZ}-\mathrm{CD}}{\mathrm{CD}} \times 100
$$

Where, SE = Solubilization efficiency $(\%)$, $\mathrm{SZ}=$ Solubilization zone $(\mathrm{mm}), \mathrm{CD}=$ Colony diameter $(\mathrm{mm})$.

Solubilization index on the solid media was calculated considering the ratio of the total (colony + halo zone) diameter and colony diameter (Edi-Premono et al., 1996).

Quantitative estimation of available phosphorous in Pikovsakaya's broth in vitro

The PSB isolates were tested invitro by estimating available phosphorus in the Pikovskaya's broth supplemented with TCP as a substrate. Cultures of PSB were inoculated to $100 \mathrm{ml}$ of Pikovskaya's broth in $150 \mathrm{ml}$ conical flask in triplicates with uninoculated controls and incubated for 10 days at $30{ }^{0} \mathrm{C}$ and centrifuged at $10000 \mathrm{rpm}$ for 10 minutes. Then separate the supernatant from cell growth and insoluble phosphate. The clear supernatant was collected in $100 \mathrm{ml}$ volumetric flasks. The available phosphorus in the filtrate was estimated by method of Olsen, 1954.

\section{pH change}

Estimation of change in $\mathrm{pH}$ of the broth due to the growth of PSB was measured with a $\mathrm{pH}$ meter at different incubation period of $3^{\text {rd }}, 6^{\text {th }}$, and $9^{\text {th }}$ day (Parimal et al., 2015).

\section{Titrable acidity}

In order to study the titrable acidity of culture medium, 5 days old cultures were centrifuged at $1000 \mathrm{rpm}$ for $10 \mathrm{~min} .10 \mathrm{ml}$ culture filtrate was taken in a $50 \mathrm{ml}$ conical flask. $5 \mathrm{ml}$ of supernatant was added with few drops of phenolphthalein indicator and titrated against $0.01 \mathrm{~N} \mathrm{NaOH}$ solution. The end point of titration was determined as pink colour. The titrable acidity was expressed as $\mathrm{ml}$ of $0.01 \mathrm{~N}$ $\mathrm{NaOH}$ consumed per $5 \mathrm{ml}$ of culture filtrate (Ponmurugan and Gopi, 2006).

\section{Phosphatase activity}

In order to study the phosphatase activity in response to the phosphorus enrichment, culture filtrate were centrifuged and subjected to estimate phosphatase activity following the standard procedure (Tabatabai and Bremner, 1969).

\section{Results and Discussion}

Total 40 PSB were isolated from 40 rhizospheric sample of rice from different paddy growing regions of Raichur and Koppal districts. Among 40 isolates, ten isolates showed the remarkable zone of solubilisation (table 1). Based on clear zone formation around colonies on Pikovsakaya's medium the solubilization efficiency and index calculated (table 1) 
Hallow zone of solubilization was ranged from $18.5 \mathrm{~mm}$ to $12.5 \mathrm{~mm}$ Plate-1 shows maximum zone of solubilization. There was a correlation with incubation time and zone size. It was also observed that increasing in the incubation time, increases the in the zone size of each isolates. Percent Solubilization efficiency was ranging from 80.95 to $253.84 \%$ from $3^{\text {rd }}$ to $9^{\text {th }}$ day of incubation period. The SE\% increased with incubation period. The solubilization index based on colony diameter and halo zone for each PSB isolate is presented in Table 1. The results showed that, among the 10 efficient isolates, the solubilization index varied from 1.80 to 3.22. The solubilization efficiency index enhanced with incubation period. The diameter of clear halo zone formed by the bacterial isolates has the direct correlation with the phosphate solubilization efficiency.

All the ten isolates were able to solubilize the insoluble phosphorus in Pikovaskaya's broth at different incubation period and were represented in table 2. Among ten isolates, available phosphorous content was ranged from 31.92 to $171.84 \mathrm{mg} / \mathrm{L}$. All the isolates were recorded decreased $\mathrm{pH}$ with increased incubation period. Among ten isolates, the reduction in the $\mathrm{pH}$ varied from 6.12 to 3.15 . The drop of $\mathrm{pH}$ was due to the production of organic acids.

The titrable acidity of the culture medium was measured. All ten isolates showed values in the range of $0.30 \%$ to $0.65 \%$. The titrable acidity increased with incubation period. The variability in the phosphatase activity of soil ranged from minimum of $16.28 \mu$ moles $/ \mathrm{g} / \mathrm{hr}$ to maximum of $42.40 \mu$ moles/g/hr with the application of PPSB-21 and PPSB-5 respectively (table 3 ). There was a positive correlation between the phosphate solubilizing capacity and phosphatase activity.

Table.1 Screening of PSB isolates for zone diameter, solubilization efficiency and solubilization index at different incubation period on Pikovsakaya's agar media

\begin{tabular}{|c|c|c|c|c|c|c|c|c|}
\hline $\begin{array}{c}\text { S. } \\
\text { No. }\end{array}$ & PSB isolates & \multicolumn{2}{|c|}{$\begin{array}{c}\text { Zone } \\
\text { diameter }\end{array}$} & \multicolumn{2}{|c|}{ Solubilization efficiency \% } & \multicolumn{3}{|c|}{ Solubilization index } \\
\hline & & $\mathbf{6}^{\text {th }} \mathbf{d a y}$ & $\mathbf{2}^{\text {nd }} \mathbf{d a y}$ & $\mathbf{4}^{\text {th }}$ day & $\mathbf{6}^{\text {th }}$ day & $\mathbf{2}^{\text {nd }}$ day & $\mathbf{4}^{\text {th }}$ day & $\mathbf{6}^{\text {th }}$ day \\
\hline $\mathbf{1}$ & PPSB1 (LGR-2) & 12.5 & 80.95 & 98.33 & 127.27 & 1.80 & 1.98 & 2.27 \\
\hline $\mathbf{2}$ & PPSB5 & 17.5 & 136.61 & 178.46 & 222.80 & 2.36 & 2.78 & 3.22 \\
\hline $\mathbf{3}$ & PPSB7 & 15.8 & 113.23 & 158.33 & 216.00 & 2.23 & 2.58 & 3.16 \\
\hline $\mathbf{4}$ & PPSB11 & 16.3 & 102.89 & 149.43 & 201.85 & 2.12 & 2.47 & 3.01 \\
\hline $\mathbf{5}$ & PPSB15 & 12.5 & 82.53 & 106.89 & 140.38 & 1.82 & 2.06 & 2.40 \\
\hline $\mathbf{6}$ & PPSB21 & 18.4 & 143.47 & 198.36 & 253.84 & 2.43 & 2.98 & 3.53 \\
\hline $\mathbf{7}$ & PPSB25 & 13.0 & 88.33 & 110.52 & 150.00 & 1.86 & 2.10 & 2.50 \\
\hline $\mathbf{8}$ & PPSB28 & 12.9 & 101.61 & 139.62 & 186.66 & 2.01 & 2.39 & 2.86 \\
\hline $\mathbf{9}$ & PPSB35 & 14.5 & 90.00 & 127.77 & 178.84 & 1.91 & 2.17 & 2.68 \\
\hline $\mathbf{1 0}$ & PPSB39 & 12.9 & 98.33 & 133.96 & 180.43 & 1.98 & 2.33 & 2.80 \\
\hline & G R -8 & 16.5 & 120.58 & 165.07 & 119.81 & 2.31 & 2.65 & 3.21 \\
\hline
\end{tabular}


Table.2 Quantitative estimation of available phosphorous in Pikovsakaya's broth in vitro and effect of PSB isolates on pH change of Pikovsakaya's broth

\begin{tabular}{|c|c|c|c|c|c|c|c|}
\hline S. No. & \multirow{2}{*}{ PSB isolates } & \multicolumn{3}{|c|}{ Amount of P released (mg/L) } & \multicolumn{3}{|c|}{ Change in pH } \\
\cline { 3 - 8 } & & $\mathbf{3}^{\text {rd }} \mathbf{d a y}$ & $\mathbf{6}^{\text {th }}$ day & $\mathbf{9}^{\text {th }}$ day & $\mathbf{3}^{\text {rd }}$ day & $\mathbf{6}^{\text {th }}$ day & $\mathbf{9}^{\text {th }}$ day \\
\hline $\mathbf{1}$ & PPSB1 & 44.89 & 82.53 & 121.44 & 6.12 & 5.88 & 5.24 \\
\hline $\mathbf{2}$ & PPSB5 & 63.90 & 104.94 & 159.90 & 3.76 & 3.58 & 3.32 \\
\hline $\mathbf{3}$ & PPSB7 & 55.63 & 93.31 & 148.53 & 4.98 & 4.21 & 3.96 \\
\hline $\mathbf{4}$ & PPSB11 & 58.59 & 99.54 & 151.59 & 5.03 & 4.75 & 4.10 \\
\hline $\mathbf{5}$ & PPSB15 & 39.43 & 79.05 & 132.43 & 5.25 & 4.83 & 4.28 \\
\hline $\mathbf{6}$ & PPSB21 & 64.84 & 110.67 & 171.84 & 3.54 & 3.37 & 3.15 \\
\hline $\mathbf{7}$ & PPSB25 & 35.67 & 76.53 & 128.67 & 5.95 & 5.14 & 4.87 \\
\hline $\mathbf{8}$ & PPSB28 & 50.23 & 90.68 & 140.23 & 5.30 & 4.96 & 4.42 \\
\hline $\mathbf{9}$ & PPSB35 & 48.13 & 87.62 & 124.13 & 6.08 & 5.84 & 5.13 \\
\hline $\mathbf{1 0}$ & PPSB39 & 31.92 & 71.21 & 118.92 & 5.65 & 5.08 & 4.24 \\
\hline & G R -8 & 60.32 & 102.07 & 155.51 & 3.90 & 3.70 & 3.40 \\
\hline
\end{tabular}

Table.3 Effect of PSB on titrable acidity of Pikovsakaya's broth and phosphatase activity of rhizosphere soil

\begin{tabular}{|c|l|c|c|}
\hline S. No. & \multicolumn{1}{|c|}{ PSB isolates } & Titrable acidity $(\boldsymbol{\%})$ & $\begin{array}{c}\text { Phosphatase activity } \\
(\boldsymbol{\mu} \text { moles/g/hr })\end{array}$ \\
\hline $\mathbf{1}$ & PPSB1 & 0.30 & 16.28 \\
\hline $\mathbf{2}$ & PPSB5 & 059 & 37.05 \\
\hline $\mathbf{3}$ & PPSB7 & 0.50 & 31.10 \\
\hline $\mathbf{4}$ & PPSB11 & 0.49 & 28.72 \\
\hline $\mathbf{5}$ & PPSB15 -1$)$ & 0.41 & 25.58 \\
\hline $\mathbf{6}$ & PPSB21 & 0.65 & 42.40 \\
\hline $\mathbf{7}$ & PPSB25 & 0.35 & 18.25 \\
\hline $\mathbf{8}$ & PPSB28 & 0.38 & 21.39 \\
\hline $\mathbf{9}$ & PPSB35 & 0.32 & 13.47 \\
\hline $\mathbf{1 0}$ & PPSB39 & 0.45 & 23.55 \\
\hline & R. strain & 0.52 & 33.00 \\
\hline & Control & 0.07 & 3.35 \\
\hline
\end{tabular}




\section{Plate.1 Isolation of PSB on PVK media}
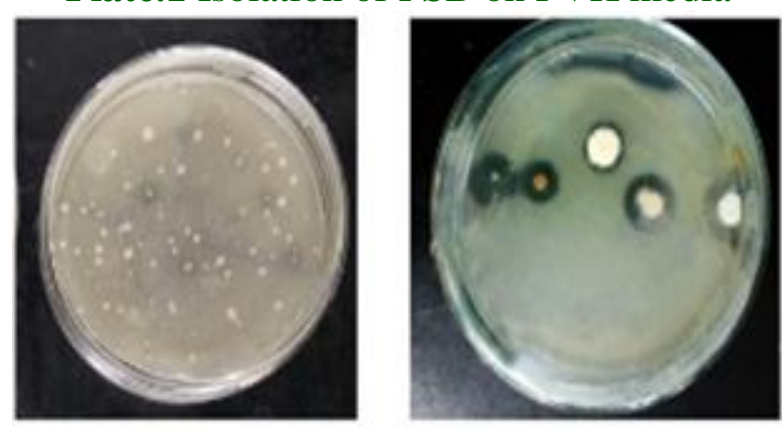

Rice is the important food grain and staple food for over the billions of people in most of the countries particularly in East Asia. It's a major part of balanced diet and rich source of energy and carbohydrate. Phosphorus is one of the essential macro-minerals for the growth and development of plant (Schachtman et al., 1998). It is a major component in ATP, the molecule that provides energy to the plant for such processes as photosynthesis, protein synthesis, nutrient translocation, nutrient uptake and respiration (Deepak kumar, 2011). But after application, a considerable amount of them are rapidly transferred into less available forms by forming complexes with $\mathrm{Fe}, \mathrm{Ca}$ and $\mathrm{Al}$ cations before roots have a chance to absorb it (Alam and Ladha, 2004).

Under such conditions PSB play fundamental role in biogeochemical phosphorous cycling in natural and agricultural ecosystem. Extensive use of chemicals as fertilizer improves the plant health and productivity but disturbed the ecological balance of soil and resulted in nutrient depletion. This has necessitated the search for alternate source of this element. The use of PSB in agriculture practice is not only offset high cost of manufacturing phosphatic fertilizers but also make availability of insoluble $P$ fertilizer.

The maximum halo zone was found with PPSB-21 with zone diameter of $18.5 \mathrm{~mm}$. The results showed that, among the 10 isolates, the PSB-21 isolate showed a maximum solubilization efficiency and index of 253.84
Plate.2 Screening of PSB isolates for solubilization efficiency on PVK media
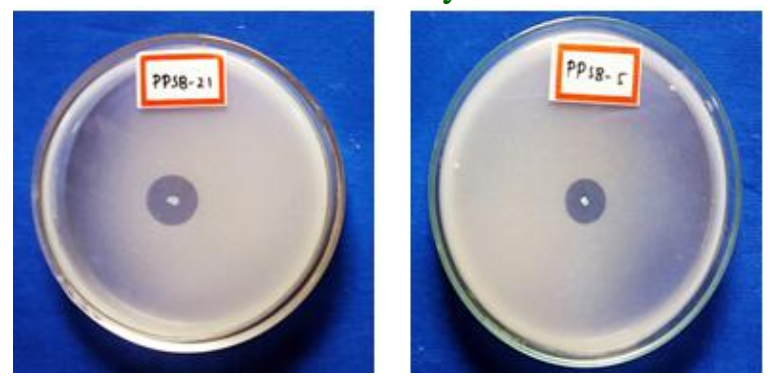

and 3.53 respectively on $9^{\text {th }}$ day of incubation period over other bacterial strains. The solubilization efficiency enhanced with incubation period. The diameter of clear halo zone formed by the bacterial isolates has the direct correlation with the phosphate solubilization efficiency. The percent solubilization increased with incubation period. Similarly, Ngomle et al., (2014) isolated ninteen PSB. The P-solubilization efficiency was found maximum in UBPS-22 $(28 \mathrm{~mm})$ followed by UBPS-19 $(25 \mathrm{~mm})$ and UBPS-18(24 mm) respectively within $72 \mathrm{hrs}$ of incubation in Pikovskaya's medium. Similar outcomes have been reported by many workers viz. Frateme et al., (2014), Deepak et al., (2018).

Among ten isolates PPSB-21 recorded the highest available phosphorous content of $171.84 \mathrm{mg} / \mathrm{L}$ on $9^{\text {th }}$ day of incubation. All the ten isolates were able to solubilize the insoluble phosphorus in Pikovaskaya's broth at different incubation period it may be due the abilities of the isolates to solubilize inorganic phosphate by the production of organic acids. Similarly, Karpagam and Nagalakshmi (2014) isolated 8 potent isolates, 3 strains showed high soluble phosphate production of $0.37 \mathrm{mgL}^{-1}, \quad 0.30 \mathrm{mgL}^{-1}$ and $0.28 \mathrm{mgL}^{-1}$ in broth culture. Similar work was carried out by Manivannan et al., (2011), Buddhi and Min-Ho (2013), Gandhi et al., (2014), Manouchehr et al., (2016), Amit et al., (2017) and Deepak et al., (2018). 
PPSB-21 showed highest reduction in $\mathrm{pH}$ of 3.15 on $9^{\text {th }}$ day of incubation. The drop of $\mathrm{pH}$ was due to the production of organic acids. Other reason like microbial respiration may also be involved for drop in $\mathrm{pH}$. Tensingh and Jemeema (2015) observed the $\mathrm{pH}$ change of upto 4.6 by the Bacillus sp. Amit et al., (2017) isolated 8 PSB isolates, among 3 isolates showed lower $\mathrm{pH}$ ranging $3.08 \pm 0.08$ to $3.82 \pm 0.12$. Similar results were obtained by Oliveira et al., (2009), Buddhi and Min-Ho (2013). Those bacteria that produced halo zones around colonies in PVK medium were able to produce organic acids in broth culture. This result is in accordance with Ogut et al., (2010). This is also in agreement with Mehta et al., (2001), Chen et al., (2006), Ponmurugan and Gopi (2012), Studies related to the production of organic acids have shown that citric and oxalic acids were two major organic acids produced by PSB (Alam et al., 2002).

Among all ten isolates, highest titrable acidity of $0.65 \%$ was expressed by PPSB-21. This might be due to reduction in the $\mathrm{pH}$ and secretion of organic acids. Results showed that strong positive correlation was found between titrable acidity and P solubilization. PSB produce phosphatase enzymes in soil, the activity of enzymes leads phosphate solubilization. There was a positive correlation between the phosphate solubilizing capacity and phosphatase activity. Phosphate solubilization occurs by production of organic acids and released by microorganisms; this release also decreases soil pH (Rodriguez et al., 2006). Organic acids solubilize insoluble $\mathrm{P}$ either by decreasing the $\mathrm{pH}$ or by the complexing the cation which is bound to the $\mathrm{P}$ (Vassilev et $a l ., 2006)$. The organic acids such as succinic acid, malic acid, propionic acid and oxalic acid are released by Phosphorus solubilizing bacteria (Panhwar et al., 2012), which chelate the cation bound to phosphate and being converted to soluble forms through their hydroxyl and carboxyl groups. Phosphatesolubilizing bacterial strains isolated were identified by biochemical tests; the isolates PPSB-21 and PPSB-5 were identified as Pseudomonas sp. and Bacillus sp.

In conclusion, our study demonstrated that many of the bacteria had $\mathrm{P}$ solubilizing properties and the ability was not exclusive to specific genera, suggesting the importance of preliminary screening in vitro for a wide range of bacteria to characterize their potent P-solubilizing or mineralizing trait. The PSB population was found higher in rhizo-sphere when compared with non-rhizosphere soil. Isolated PSB strains were able to solubilize P, produce organic acids, and enzymes. These beneficial characteristics would be considered as potential biofertilizer of isolated PSB for rice production.

\section{References}

Abd-Alla, M. H., 1994, Phosphatases and the utilization of organic phosphorus by Rhizobium leguminosarum biovar viceae. Lett Appl Microbiol. 18: 294296.

Alam, S., Khalil, S., Ayub,N., Rashid, M., 2002, Invitro solubilization of inorganic phosphate by phosphate solunilizing microorganisms (PSM) from maize. Int. J. Agric. Biol., 4: 454-458.

Amit, P., Prashant, P., Simmi, M., Mritunjay, S., and Suresh, K., 2017, Phenotypic and genotypic characterization of phosphate solubilizing bacteria and their efficiency on the growth of Maize. J. of Genet. Eng. and Biotechnol., 15: 379391.

Buddhi, C. W. and Min-Ho, Y., 2013 Phosphate solubilizing bacteria: Assessment of their effect on growth promotion and phosphorous uptake of mungbean (Vigna radiate L. R. Wilczek). Chilean J. of Agril. Res.,73(3). 
Chen,Y. P., Rekha, P. D., Arun, A. B. and Shen, F.T., 2006, Phosphate solubilizing bacteria from subtropical soil and their Tricalcium phosphate solubilizing abilities. Appl. Soil Ecol., 34: 33-41.

Edi-Premono, M., Moawad, A. M. and Vlek, P. L. G., 1996, Effect of phosphate solubilization Pseudomonas putida on the growth of maize and its survival in the rhizosphere. Indonesian J. Crop Sci., 11: 13-23.

Deepak, V. and Kirti, S., 2011, Nutritional value of rice and their importance. Indian Farmer's Digest. ISSN 05371589.

Deepak, P. and Chayanika, P., 2018, Isolation and characterization of phosphate solubilizing bacteria from the rhizosphsere of potato plant. Int. J. Curr. Microbiol. App. Sci. 7(1): 967975.

Fateme, F., Ibrahim, I., 2014, Isolation and characterization of some phosphate solubilizing microorganism from rhizosphere. Int. J. Biosci., 5(3): 260265.

Gandhi, A., Muralidharan, G. and Sudhakar, E., 2014, Isolation and identification of elite phosphate solubilizing bacteria from soil under paddy cultivation. Int. Letters of Natural Sci. 11(1): 62-68.

Gyaneshwar, P., Naresh, K. G., Parekh, L. J. and Poole, P. S., 2002, Role of soil microorganisms in improving $P$ nutrition of plants. Pl. Soil, 245: 83-93.

Isherword, K.F., 1998, Fertilizer use and environment In: Ahmed, N. and Hamid, A.(eds), Proc. Symp. Plant Nutrition Management for Sustainable Agriculture Growth. NFDC, Islamabad. pp. 57-76.

Jackson, M. L., 1973, Soil chemical analysis. Prentice Hall of India. Pvt. Ltd, New Delhi, p. 498.

Kannapiran, E. and Sri Ramkumar, V. 2011,
Isolation of phosphate solubilizing bacteria from sediments of Thondi coast, Palk Strait, Southeast coast of India. Annals of Biological Res., 25: 157-163.

Karpagam, T. and Nagalakshmi, P. K., 2014, Isolation and characterization of phosphate solubilizing microbes from agricultural soil. International Journal of Current Microbiology and Applied Sciences, 3(3): 601-614

Kumar, A., Kumar, A., Devi, S., Patil, S., Chandani, P. and Nagi, S. (2012), Isolation, screening and characterization of bacteria from rhizospheric soils from different plant growth promotion activities: as in vitro study. Recent res. in sci. and tech., 4(1), 01-05.

Manouchehr, T., Javad, A., Maryam, K. and Abdolrazagh, M., 2016, Assessment of phosphate solubilization activity of rhizobacteria in mangrove forest. Biocatal. Agr. Biotechnol., 5: 168-172.

Oliveira, C.A., Alves, V.M.C., Marriel, I. E., Gomes, E.A., Scotti, M.R., Carneiro, N. P., Guimaraes, C.T., Schaffert, R.E. and Sa, N.M.H., 2009, Phosphate solubilizing microorganisms isolated from rhizosphere of maize cultivated in an oxisol of the Brazilian Cerrado. Soil Biol. Biochem., 41: 1782-1787.

Olsen, S. R., Cole, C. V., Watanable, F. S. and Dean, L. A., 1954, Estimation of available phosphorous in soil by extraction with sodium bicarbonate. $U S$ Government Printing Office USDA Washington, D.C. Cire. pp. 939.

Panhwar, Q.A., Radziah, O., Zaharah, A. R., Sariah, M, and Mohd. Razi, I., 2011, Role of phosphate solubilizing bacteria on rock phosphate solubility and growth of aerobic rice. J. Environ. Biol., 32: 607-612.

Panhwar, Q.A., Othman, R., Rahman, Z.A., Meon, S., Ismail, M. R., 2012. Isolation and characterization of phosphate- 
solubilizing bacteria from aerobic rice. African Journal of Biotechnology. 11(11), 2711-2719

Parimal, P., Somsubhra, C., Ray, D. P., Bisweswar, M., Bappa, P. and Ashok, C., 2015, Solubilization of tricalcium phosphate and production of IAA by phosphate solubilizing bacteria isolated from tea rhizosphere soil. Economic Affairs, 60(4): 805-809.

Pikovskaya, R. I., 1948, Mobilization of phosphates in soil in connection with the vital activities of some microbial species. Mikrobiologiya., 17: 362-370

Ponmurugan, P. and Gopi, C., 2006,

Distribution Pattern and Screening of Phosphate solubilizing bacteria isolated from different food and forage crops. $J$. Agron., 5(4): 600-604.

Rengel, Z. And Marschner, P., 2005, Nutrient availability and management in the rhizosphere: exploiting genotypic differences. New Phytol., 168: 305-312.

Rodriguez, H. and Fraga, R., 1999, Phosphate solubilizing bacteria and their role in plant growth promotion. Biotechnol $A d v .$, 17(4-5): 319-339.

Rodríguez, H. and Fraga, R., 1999, Phosphate solubilizing bacteria and their role in plant growth promotion. Biotechnology advances, 17(5): 319-339

Rodri'guez H.R. Fraga,T. Gonzalez
\&Y.Bashan 2006 Genetics of phosphate solubilization and its potential applications for improving plant growth-promoting bacteria Plant and Soil (2006) 287:15-21

Schachtman, D. P., Reid, R. J., and Ayling, S. M., 1998, Phosphate uptake by plants from soil to cell. Pl. Physiol. 116: $447-$ 453.

Tabatabai, M. A. and Bremner, J. M., 1969, Use of p-nitrophenyl phosphate for assay of soil phosphatase activity. Soil Biochem., 1: 301-307.

Tensingh, B. N. and Jemeema, B. P., (2015), Isolation, identification and characterization of phosphate solubilizing bacteria (PSB) isolated from economically important crop plants. Int. J. Curr. Microbiol. App. Sci., 4(3): 915-924.

Vassilev, N., Vassileva, M. and Nikolaeva, I., 2006, Simultaneous P-solubilizing and biocontrol activity of microorganisms: potentials and future trends. Appl. Microbiol. Biotechnol. 71:137-144.

Zhu, F., Qu, L., Hong. X, and Sun. X., 2011, Isolation and characterization of a phosphate-solubilizing halophilic bacterium Kushneria sp. YCWA18 from Daqiao Saltern on the coast of yellow sea of China. Evid-Based Complement Altern. pp: 1-6.

\section{How to cite this article:}

Eramma, Mahadevaswamy, Satyanarayana Rao, Y. M. Ramesh and Nagaraj M. Naik. 2020. Isolation and Screening of Phosphate Solubilizing Bacteria from Paddy Rhizosphere Soil. Int.J.Curr.Microbiol.App.Sci. 9(02): 477-485. doi: https://doi.org/10.20546/ijcmas.2020.902.059 